\title{
"Stachtopouta" and "Nifitsa": spinning tales in relation with feminine productivity and dowry practices of modern Greece
}

\author{
Marianthi Kaplanoglou \\ National and Kapodistrian University of Athens \\ mkaplanog@phil.uoa.gr
}

\begin{abstract}
Stachtopouta (ATU 5IOA), one of the most popular tales in the Greek folk tradition, has justly received much attention in the pioneering and innovative approaches of D. Loukatos, Photeini P. Bourboulis, Nicole Belmont, Anna Angelopoulos, Margarita Xanthakou and Aigli Brouskou. In her analysis of the Greek Cinderella, Emmanouela Katrinaki not only summarizes the existing psychoanalytical approaches based on the rare matricide-cannibalistic element the tale contains but also places the tale in the framework of other folktales in which the theme of imaginary cannibalism appears. Another solid theoretical framework has been provided by Francisco Vaz da Silva in a series of articles about the European (including the Greek) Cinderella based on the concept of allomotifs, their symbolic equivalences and their comparison with correlated folk customs. Nifitsa, on the other hand, one of the most common animals in Greek fauna is the heroine of an equally well known but less studied belief story. Though belonging to different narrative genres - the folktale and the legend respectively - these two stories evolve around the common theme of spinning. By studying the narrative appropriation of this theme, the present paper tries to establish the affinities and differences between the variants of these stories taking in terms of their geographical and social anchorage. In this framework issues regarding feminine productivity and dowry accumulation practices in modern Greek communities seem to play an important role in folktale variation.
\end{abstract}

KEYWORDS

spinning tales; traditions; Balkan; Greek; kinship practices 


\section{RESUM}

Stachtopouta (ATU 5IOA), una de les rondalles més populars de la tradició folklòrica grega, ha rebut recentment molta atenció des dels enfocaments pioners $i$ innovadors d'estudiosos grecs $i$ estrangers com ara D. Loukatos, Photeini P. Bourboulis, Nicole Belmont, Anna Angelopoulos, Margarita Xanthakou i Aigli Brouskou. Emmanouela Katrinaki, en el seu propi anàlisi de la versió grega de la Ventafocs, no només resumeix els enfocaments psicoanalitics existents basats en el rar element del matricidi de la rondalla grega sinó que també la col-loca en el marc d'altres rondalles en què apareix el tema del canibalisme imaginari. Un altre marc teòric sòlid ha estat proporcionat per Francisco Vaz da Silva en una sèrie d'articles sobre les versions europees (inclosa la grega) basat en el concepte dels allomotifs, les seves equivalències simbòliques i la seva comparació amb els costums populars correlacionats. Nifitsa, d'altra banda, un dels animals més comuns de la fauna grega, és l'heroïna d'una història de creences igualment ben coneguda, però menys estudiada. Encara que pertanyen a gèneres narratius diferents, la rondalla i la llegenda, respectivament, aquestes dues històries s'articulen entorn d'un mateix tema, l'activitat de filar. A través de l'estudi de l'apropiació narrativa d'aquest tema, aquest treball intenta establir les afinitats i les diferències entre les variants d'aquestes històries, tenint en compte la importància del seu ancoratge geogràfic i social. En aquest marc, les qüestions relatives a la productivitat femenina i les pràctiques d'acumulació de dots en les comunitats gregues modernes semblen tenir un paper important en la variació folklòrica.

Paraules Clau

rondalles de filar; tradicions; Balcans; Grècia; pràctiques de parentiu

REBUT: 09.I2.20I4 | ACCEPTAT: I9.OI.2OI5 
"Stachtopouta" and "Nifitsa": spinning tales in relation with feminine productivity ...

\section{Introduction}

In a previous essay, ${ }^{\mathrm{I}}$ I dealt with the symbolism of spinning in the Greek Cinderella (Stachtopouta, from the word stachti = ashes) in terms of the archaic element of matricide (and matriphagy) which emerges in expressive or latent narrative form. Stachtopouta was examined in parallel with folkloric and mythological data about spinning and cannibalism, with particular emphasis on some of their lasting symbolic references. The present paper focuses on an additional parameter of spinning symbolism.

We may wonder what connotations these old symbols have for modern folktale audiences, justifying Stachtopouta's popularity. To answer this question the flexibility of folktale symbols should be explored in relation with their more ephemeral social contexts of use; in living folklore systems (such as the ones provided by Greek local communities) folktales vary as a result of this constant interaction between existing or even archaic narrative themes and their appropriation by a narrative community. The interdependence of worldwide symbols with the micro-data and micro-ethnographic parameters in particular contexts of social organization is made apparent in many spinning tales where the role of women as mothers and daughters is constantly negotiated in the framework of patriarchal local communities.

We will then proceed to examine versions of Stachtopouta and the relation these narratives have with the corresponding social realities and matrimonial systems. Then we will explore how these realities are negotiated in the story of the weasel (in Greek called nifitsa, literally "little bride"), in the framework of another narrative genre, the legend.

\section{The popularity of spinning tales in Greek folk culture}

The Catalogue of Greek Magic Folktales (Megas et alii 20I2) and more recently collected material indicate that spinning tales are abundant in Greek folk narrative repertoires. During my field research in the islands of the Aegean I noticed that storytellers, especially women, tend to use spinning as a wandering or passepartout motif. The very act of storytelling itself is considered as a metaphor of spinning as the usual introductory formula of Greek folktales shows:

Red thread tied,

in the spinning - wheel rolled up,

give it a kick to turn,

in order for the tale to begin.

Here the thread is the thread of the clothing that women produce during their collective night work (nichteri) but it is also the thread of the story that the narrator tells to keep them awake, and the thread of time that prolongs the night so that they can finish their job.

This formula of Greek narrators reflects a social reality: the essential role of spinning, its implements (distaff, spindle, etc.), its material (un-spun wool, flax,

I. Both articles are based on a paper read at an international conference (2O-2I June 20I3) organized by the Folklore Archive of the Department of Catalan Studies at the Rovira i Virgili University to commemorate the life and work of Josep Maria Pujol. 
hemp, etc.) and its products (thread, yarn, etc.) in women's everyday activities. It also draws on the many symbolic connotations of spinning (and weaving) concerning human existence itself (birth, marriage, initiation of a girl into womanhood, death, fate) in the framework of a rich, long and varied tradition dating from the Greco-Roman times (Scheid and Svenbro 2003). According to both ancient and modern folk beliefs, spinning is an analogy of human life. The spinning continues while a man is still alive. When the spinning stops, and the thread of life is cut, a man dies. The length of the thread to be spun is determined by the three mythical spinning Fates at birth (Megas I967: 316-32; Lawson I9IO: I23I24). The relevant euphemism for dying is "his thread was weltered or finished".

Accordingly, spinning represents a symbolic expression of pregnancy and motherhood. As argued by Mirjam Mencej on the basis of the comparison of beliefs from different European sources, there is a symbolic equivalence between the state of a child before birth (i.e. in the other world where new souls come from) (Vaz da Silva 2008: 46) and the un-spun wool, and also between a child born into this world and the spun thread (Mencej 20II: 66-69). Therefore, according to these beliefs, the procedure of turning the un-spun wool to spun-thread creates a symbolic equivalence between spinning and conceiving.

Spinning also represents a test of marital initiation: thus three poor girls spin and talk during the nichteri, while the king, who has forbidden lights to be turned on in the town during the night, overhears their conversation and chooses the third sister as his wife (ATU 707 The Three Golden Sons). Alternatively, the cause of feminine jealousy is the ability of the heroine to spin and weave better than her sisters, and thus to catch the prince's attention (ATU 709 Snow White).

The theme of spinning is also found in legends, anecdotes or obscene stories which parody the rules of social interplay, marriage rites and acceptable social roles for women: for example, the plot of the Greek oikotype $902 \mathrm{C}^{*}$ about a newly married woman who settles in her husband's house and is forced by her motherin-law to spin long after midnight, so she cannot sleep enough. She is delivered from this nocturnal work thanks to the intervention of her brother who visits her and threatens her mother-in-law to change this habit.

\section{The two traditions of Stachtopouta}

Stachtopouta is one of the most widely known folktales in Greek tradition. A total of 254 versions (of the ATU 5IOA subtype) are mentioned in the Catalogue of Greek Magic Folktales and numerous others have been collected from more recent field research. This oral tradition is quite different from the famous West-European printed versions in which the orphan girl abused by her stepmother is given a dress, shoes, and a carriage by a fairy so that she can go to the ball, where she loses her shoe and the prince falls in love with her. As is the case with the international type, the Greek versions display considerable variety in the tale's introduction, where we can discern two forms of introductory episodes and many intermediary forms. Unlike the heterogeneity of the introductory motifs, the structure of the main part of the tale is quite stable, consisting of episodes and motifs from ancient sources (Ben-Amos 2OII: 42O-42I). These two main traditions (according to the two distinct forms of introductory episodes)are distinguished not only by their plot elements but also by their different geographical distributions. 
"Stachtopouta" and "Nifitsa": spinning tales in relation with feminine productivity ...

\subsection{The Balkan-Slavonic tradition}

The first tradition, encountered mostly in continental northern and central Greece (Greek Macedonia and Thessaly), is part of the Balkan-Slavonic tradition of the tale: the heroine spins with other girls outdoors and in spite of the warnings that if one of them does not do her job properly her mother will be transformed into an animal (cow), she fails to accomplish the task: she does not spin the amount of wool required before the deadline, she is the last to finish, she drops her spindle into a well, she eats the un-spun wool or she jumps over the ashes from the fireplace instead of spinning. So her mother is transformed into a cow. The father remarries and her new stepmother gives the heroine a large amount of wool to spin. This time the task is performed by a helpful animal (her transformed mother) which spins in her place (in Serbian versions she puts the wool in her mouth, chews it and produces the thread from her ear or, in some Greek versions, she temporarily assumes her human form to perform the task). The stepmother discovers what has happened and kills, cooks and eats (along with other members of the family) the cow. Stachtopouta, who does not take part in this cannibalistic supper, gathers the bones, buries them under the fireplace or somewhere else inside or near the house, and performs burial rites. After the appropriate time of mourning has passed (forty days), inside her mother's grave she finds the dresses that will allow her to look her best at her meeting with the prince.

\subsection{The Greek oikotype}

The second subplot is better known and it is commonly found throughout Greece; nevertheless, it is dominant in southern Greece and the Aegean islands where the Balkan tradition is almost non-existent.

Three poor sisters spin with their mother in order to earn their living. In the midst of a famine they make a bet that whoever is last to finish their work, drops the spindle or breaks the thread will be killed and eaten by the others. The mother loses the bet (three consecutive times) and her two elder daughters kill and eat her. Stachtopouta, the youngest, does not take part in the cannibalistic supper, gathers the bones, buries them (inside the house or under the ashes of the fireplace) and performs the appropriate burial rites (burns incense or mourns her mother for forty days or even as long as one to three years depending on the funerary customs of the region). At the end of this period she finds dresses in her mother's grave or her mother's bones are transformed into beautiful garments.

The folktale continues with the well-known episodes of the heroine's appearance at the church (three consecutive times), the loss of the shoe, which the prince finds and then gets all the maidens to try on so that he can find his future bride. Recognition follows and the folktale concludes with the heroine's marriage.

The tale often continues as ATU 707 (The Three Golden Children) or as 403B (The Black and the White Bride): her envious sisters punish the heroine by stealing her babies, transforming her into a bird and taking her place at the prince's side until they are finally punished and the heroine resumes her human form. 


\subsection{The "intermediary" versions}

A number of intermediary versions show different levels of appropriation of one plot by the other. One version collected at the beginning of the $2 \mathrm{O}^{\text {th }}$ century by the French Hellenist Louis Roussel from the island of Myconos (Aegean Sea) is a typical example of this fusion (Roussel I929: III-II2). A woman had three daughters who made spindles. The eldest daughter said that whoever dropped their spindle would be turned into a sheep. The mother dropped hers so they turned her into a sheep. The youngest daughter grazed her while she made spindle from two curls of unspun wool. The mother was then transformed back into a human being and did the spinning instead of her daughter. Her sisters asked: "Stachtamara, Stachtapodotilimeni (she whose foot is covered with ashes) how did you manage to spin so quickly?". The sheep acted aggressively to the elder daughters, so they decided to kill it, cook it and eat it. During this time, the heroine, following her mother's instructions, refused to eat her and rolled about in the ashes. She then gathered up her mother's bones, put them inside a hole in a tree and lit a candle for forty days. At the end of this period of time she discovered some magnificent dresses inside the hole. She wore them to church.

Thus in "intermediary" versions the spinning bet of the oikotypical subplot coexists with the transformation of the mother into an animal that is mostly a feature of the Oriental and European tradition of the tale.

\subsection{The heroine's name}

The heroine's name in Greek tradition always recalls the enigmatic figure of a maiden sitting or covered with ashes (stachti or athos in Greek). The second part of the name usually refers to the poutti, which means the female genitals (Stachtopouta, Atho-poutaki etc.).

As an inorganic substance produced from an organic substance, ashes were a multi-purpose material in Greek folk culture: they were used to produce stachtonero (water with ashes) which, in turn, was used to make or preserve food, wash dishes, polish metal objects and launder clothes (Polymerou-Kamilaki 20I3: 33). The remaining ashes, which may contain some organic material (carbon, wood etc.), were collected during the winter and used in February and March to purify the soil by putting a small amount in the roots of fruit trees, vines, vegetables and legumes. Additionally, phragmites were often burned in cereal fields prepared for plowing to destroy insects and fertilize the soil (Polymerou-Kamilaki 20I3: 37).

These practical uses formed the basis of the symbolic dimension of ashes in customs and narratives as a metaphor of death and a means of rejuvenation. In Greek folk thought, the hearth (hestia) is regarded as an entrance to the underworld and a place where children come from. In Pontus the last-born child was named "tzakoter" or "tzakotirin" (coming from the fireplace) (Sergis 2007: 9I-92). In the community of Achialos on the west coast of Pontus, sick children were passed over the fire or were circulated around the fireplace in order to be cured. The first of these customs was a process of purification; the second, a birth or re-birth (Megas I943-44: 47-48).

As a rule, Stachtopouta buries her mother's bones inside the house, usually under or near the fireplace. In one of the earliest recorded versions, she buries 
"Stachtopouta" and "Nifitsa": spinning tales in relation with feminine productivity ...

the bones of her mother under the stachtologo (a special place near the hearth or the oven) in order to "smoke" them until the 40 days and nights were over (Hahn I864: 7I; Pio I879: 6). This is the moment at which the heroine withdraws to ashes herself. As many narrators emphasize, the girl is covered with ashes (hence her name) not at the beginning of the tale but long afterwards, usually after her mother's death (in southern versions). The very name of Stachtopouta then, following Vladimir Propp's insight that the folktale hero who appears from the fireplace is a dead person coming back to life, seems to support the idea that the event is a symbolic expression of re-birth. From different narrative paths, Greek tales conform with other European Cinderellas in which cinders are deathconnoting symbols; the heroine, covered with the ashes from the fireplace, is relegated to a temporary death only to emerge as a living image of her mother (Vaz da Silva 2000: I64).

In northern versions following the Balkan tradition, Stachtopouta withdraws to ashes while her mother-cow spins the un-spun wool into thread: could these two conducts which are connected from a narrative point of view (they appear in parallel in the plot) also be symbolically connected? Thus the heroine sitting in the ashes (as her name indicates) and the spinning mother-cow form two complementary symbolic images of the same birth or rebirth process.

\subsection{The spinning}

The theme of spinning connected with indirect matricide (the transformation of the mother into a cow) is at the core of the Balkan versions of Cinderella. Spinning is again central to the southern Greek plots, but this time in combination with direct matricide. Middle Eastern and Mediterranean versions in which matricide is also present have a totally different motivation. A mother-helpful animal (cow) which spins wool for her daughter or nourishes her children from her horn is also present in some central Asian versions of the tale which involve an episode of direct matricide. In Europe and the Orient, the motif of the helpful animal is connected with the motif of the dead mother as helper (Wehse I98I: 44; Ting I974: II). According to Rooth, the regeneration of the mother into one form of existence or another "is something that developed in the Oriental tradition" (Rooth I95I: I55).

It is therefore possible that the spinning theme in the matricide episode of the versions from south Greece is a loan from an analogous fusion: What is only implied in the oriental versions in which the mother-cow is killed, cooked and eaten by her other relatives (since other daughters are not mentioned) becomes explicit in the southern Greek versions.

Both themes reflect the close relationship that Cinderella has with her mother. Nevertheless, even if spinning is perceived as technical knowledge transferred from mother to daughter, as well as a symbolic expression of initiation, it is evaluated differently across different versions and narrative traditions.

In the versions of Cinderella from central and northern Greece and from other Balkan areas, spinning is presented as a collective activity of a group of young girls who are relatives, neighbors or, in some versions, other girls. The spinning is interrupted as a result of the heroine's laziness or of symbolically charged events (she drops her spindle in the well, she eats the unspun wool). After her death 
Stachtopouta's mother is reincarnated as an animal (cow, sheep) who breastfeeds her child and spins abundant amounts of thread out of her body. Both attributes are connected with the feminine body and provide complementary metaphors of motherhood. Excessive or supreme spinning is usually attributed to supernatural beings (goddesses, saints or holy animals). The nereids (fairies) of Greek folk beliefs, for example, are always in the mood for spinning and can spin endlessly or can procure a ball of thread which never finishes. Likewise, the nereids and the lamias are figures with big breasts which they throw over their shoulder to feed their babies while simultaneously they knead. Like mythical feminine beings connected with lactation, nourishment and spinning, the mother of the heroine is therefore associated with fertility, abundance and the making of children.

A different imagery is used in the second oikotypical subplot in which the theme of hunger prevails. Unlike the Balkan tradition (where archaic material symbols with regard to spinning prevail), southern versions seem much more preoccupied with the economic aspect of spinning and they describe an initial situation of extreme poverty and female antagonism. The young girls are impoverished or even starving and despite their hard work they cannot guarantee that they will ever have a dowry, which will enable them to marry. In fact, they spin "other girls' clothing or dowries", not their own. In a version from Mani, the Peloponnese (Kassis I983: I33-I34), a mother with three daughters spins constantly throughout the nichteri in order to produce more thread, sell it and earn money. In a version from the island of Cephalonia (Ionian Islands) a poor mother and three daughters spin other peoples' cotton in order to earn their living (Loukatos I977: 266-289). The cannibalistic spinning bet is again connected with starvation and a shortage of resources (wool). A husband will be found not as a result of spinning but through magic, and only for Stachtopouta with the help of her dead mother. Thus the powerful animal-spinner of the Balkan versions is replaced in the oikotypical ones by the latent figure of a grateful dead family member (again the mother) who, even if she does not actually spin, procures the magnificent clothes for the heroine.

\subsection{The mother's gifts}

The gifts from the dead mother are a central theme of the tale but it varies considerably. In $19^{\text {th }}$ century versions of Stachtopouta, in accordance with the character of a tale of magic, the magical character of the motif is given particular emphasis. In the earliest recorded versions of Stachtopouta (Das Ausland 1832: 230), the heroine is given golden dresses while in a version from Kukuli, Epirus (published by Johann Georg von Hahn in I864), the well known motif of the three magic dresses which are decorated with the heaven and the stars, the earth and its flowers, the sea and fish first appears. In a version from Zagoria, Epirus, the heroine finds, golden florins in the place where she had buried her mother's bones. She throws them to the people gathered in the church in order to escape (Journal of the Hellenic Philological Society of Constantinople I879-80: 256). In a Cypriot version collected by Sakellarios (Kypriaka I89I: 3II), the mother's bones have been transformed into gold and diamonds. In a Pontic version (Astir Pontou I885: 2I3-2I7), the dress contains elements of the local costume but it is again made of gold. In a Cretan variant of the tale (Zografakis I886: 4) inside her 
mother's grave the heroine finds golden clothes, golden shoes and two golden partridges who announce her coming to the church.

The motif of the three magic dresses remains dominant in later recorded versions (see, for example, a version from Mani in Kassis I983: I35). The motif of the golden garments, however, is equally popular: in a version from Voion, Greek Macedonia the heroine opens the jar where she guards her mother's bones to find that they have been transformed into gold: clothes, chemises, slippers, and candles (Papanikolaou I999: 489). In some versions the magic dresses are hidden inside a nut (walnut, hazelnut, almond) (a version from Skiathos published by Rigas I962: 60 and from Chios in Argenti-Rose I949, vol.I: 443) or inside magical fruits (a version from the area of Trikala, Thessaly in Papazisi-Papatheodorou I996: 77-85). A version from Patmos presents a combination of motifs: inside the jar with her mother's bones the heroine finds three magic dresses, other garments of the local costume and golden florins (Virvillis I996: 34-35). In an unpublished version from the island of Milos (Aegean Sea) a golden horse, a dress, shoes and other things appear when the heroine opens three nuts. Nevertheless, in some versions, more realistic things replace the magic objects. From the bones of the mother, a dress, shoes and a horse appear (see the version from Kassandra, Greek Macedonia in Ioannou I987: 322 and the version from Divri, Central Greece in Georgamlis 2002: 9). In a Pontic version, the jar is transformed into a horse and the mother's bones into dresses (Papadopoulos I937: 158).

As well as this shift between magic and realism, variation occurs between more modest findings and a tendency for accumulation. In a version from Monemvasia, the Pelopponese (recorded in the beginning of the $2 \mathrm{O}^{\text {th }}$ century but published a century later in Kougeas 2009: 76), there are as many golden dresses as bones. The same thing happens in a version from Rethymno (Crete) in which every one of the heroine's mother's bones turns into a valuable object (dresses, shoes, jewellery) (LF II65 in Angelopoulos I991: 56). In a version from the island of Myconos (Aegean Sea), inside the hole of a tree where she had put her mother's bones the heroine discovers a box full of golden dresses, golden shoes, golden bracelets, golden gloves, a golden horse, liras, diamonds and gemstones (Roussel I929: III-II2). In a version from the island of Kythnos (Venetoulias 2OOI: 84) many gifts appear from the ashes: dresses, other garments, jewellery, shoes, perfumes, etc.

In one version of the tale (narrated to me in 2002 in western Crete by a woman in her seventies), the heroine asks the king to bring camels with him and, when they arrive, she opens her mother's grave and she finds a big dowry inside that needs all the camels to be moved to the prince's palace. The last episode of the tale contains a description of a series of other prenuptial customs, such as the public exhibition of the dowry, the wedding procession, the local folksongs (rizitika) and the marriage flag (bairaki). In accordance with the proverb "a marriage cannot take place without a dowry", the accumulation of a big dowry which will permit the heroine, unlike her sisters, to marry becomes the central point of the narrative. When her elder sisters ask for a piece of the dowry, the heroine refuses and condemns them to celibacy.

In another Cretan version (LF II65), the heroine asks for a carriage which is loaded with all the things found in her mother's grave. There are so many, however, that they do not all fit in. In an unpublished version from the island of 
Kos (Aegean Sea) the heroine asks for forty horses and loads them with her big dowry. She responds to the pleas of her sisters in the following way: "You killed our mother and ate her. I gathered her bones, put them in the jar and incensed them for forty days and my mother gave all this to me. It was my mother's blessing". In a version of the tale told in the island of Kassos (Aegean Sea) the elder daughters wonder how their sister acquired all these beautiful golden dresses. Stacthopouta answers, "All these golden dresses are the blessing of my mother because I didn't eat her flesh but burned incense on her bones". In a version from Messinia in the Peloponnese, the clothes and the money were offered to Stachtomaro by her mother because she buried and incensed her bones (Theochari I994: II7).

In general, narrators of the southern versions make it clear that what Stachtopouta finds in her mother's grave is beyond her wildest dreams. On the contrary, in northern versions, the mother's magical or realistic gifts, remain within the bounds of reason.

\section{The social aspects of spinning: feminine productivity and dowry accumulation}

Could the two different narrative traditions and therefore the two different symbolic frameworks have some connection with patterns of devolution and the kinship practices of the folk groups among which the tales circulated? By this I do not mean that the folktale is an immediate reflection of economic and social relations; rather it constitutes an imaginatively elaborated formulation of their historical being.

From a social point of view, the objective of spinning was to provide a young girl with dowry. A dowry confirmed a woman's productive force and her social status (Bada 2002; Korre-Zografou 2004-IO). We can assume that a girl could spin her way to marriage and acquire the status of a bride. Nevertheless, this socially accepted, traditional feminine attribute was evaluated differently depending on the economic and kinship relations of different communities.

As mentioned above, the northern versions of Stachtopouta have an archaic symbolic framework that associates spinning with fertility, abundance and child-bearing. This symbolic framework seems to be in accordance with an archaic form of economic and social organization which affected the status of women in the productive process. During the Ottoman and post-Ottoman period, the nomadic-herding populations of Northern Greece and the Balkans, despite their regional differences, shared certain characteristics regarding the devolution of property and the role of women in the production of goods. Their economic system of self-subsistence was based on the kinship relations of the extended family as an agricultural or agro-pastoral unit of production. ${ }^{2}$ Referring to the basic family organization of the Slaves of the south, the zadruga, Sicard defines four communitarian principles: community of blood (agnatic relationship), community of life (domestic group), community of goods (which does not signify perpetual indivision, it can every moment exist partage) and

2. According to Stoianovich, the domestic family was the dominant type of family in most of the Balkans from the $16^{\text {th }}$ to the $19^{\text {th }}$ centuries because it usually functioned satisfactorily as a unified entity and as a collective group (Stoianovich I976). 
community of work (Sicard I943). ${ }^{3}$ In the pre-capitalist traditional structure and family organization of production, the productive force, the means of production and the productive procedure remain inside the family. Work is organized by the family, for the family (Rokou 2007: I64-I65).

This system of family organization was connected with a patrilocal system of residence, a patrimonial system according to which the sons of the family stay under the paternal roof after their marriage while the daughters, who were excluded from the division of the parental property, went to live in their husband's house. ${ }^{4}$

In these self-subsistence, patriarchal, inter-family economies of extended families, women were useful for collective work and the production of goods, so what they had to offer in terms of a dowry when they married was limited to some goods (clothes and utensils) for their new home. In fact, instead of giving, women took - or more correctly her family took - a sum of money as compensation. ${ }^{5}$ Marriage, therefore, as an economic strategy did not aim to transfer wealth but to transfer a working force (women) and reinforce a family's productive capacity (Gossiaux I996: I93; Papataxiarchis-Petmezas I998: 219).

These systems and matrimonial strategies assumed some recognition, at least in the collective imagination, of a feminine force, which the social construction of gender roles inside a patriarchal system of family organization has deprived women of. But again this occurs on a restricted, family level - not a social one since it defines the mother-daughter relationship. Likewise, spinning, as part of a limited direct dowry system, was also deemed to be a practical means of procuring everyday goods, like clothing, and did not acquire any big exchange or monetary value. This archaic function of self-subsistence (in which the productive forces formed part of the social organization of the family group) permitted then to an older narrative-ritualistic framework designing femininity to survive.

In southern Greece, however, there were many different types of families because of the particular geographical and economic conditions and in general, different devolution systems prevailed. Could this correspond to a different emphasis put on spinning and dowry accumulation in the economic and devolution systems of southern Greece? Unlike the matrimonial system of the pastoral populations of northern Greece where the dowry is practically non-existent or restricted to the necessary household items, in southern Greece and the Aegean islands, direct dowry was a very important factor in the inheritance system and marriage rituals. Until the end of the $19^{\text {th }}$ century, the local communities of mainly continental Greece that specialized in family agriculture favored a successoral system of partible inheritance based on patrilocality, which succeeded in endowing all descendants (irrespective of sex

3. He recognizes that the organization of Albanian and the Bulgarian families presents certain analogies.

4. The pastoral, sometimes mixed agricultural economies of central and northern Greece were also based on male equal partible inheritance at the expense of female descendants who were basically excluded from any share in the patrimony. This is the case for the pastoral populations of central and northern Greece, like the Sarakatsans (Campell I964).

5. It is the same with farmers working in the big agricultural domains of Thessaly (Meraklis 2004: 58-59). According to Alexakis, the bride price, in its actual or symbolic forms coexists with multi-nuclear families and patrilateral groups (Alexakis I999-2003: 46). 
and age) with the resources they needed to set up as independent domestic units. The dowry included land, a house and the trousseau prepared by the women themselves, although over time it slowly became monetized. Dowry inflation was the mechanism through which a monetized surplus was accumulated and redistributed among the peasant families (Papataxiarchis-Petmezas I998: 230).

The maritime and agricultural communities of the Aegean islands, on the other hand, favored nuclear, matrilaterally extended households. Daughters often had more privileges than sons in terms of the transmission of property. Dowries consisted of houses, land and a trousseau. They were faster than in other regions, monetized and inequalities between inheriting offsprings were sharper (Papataxiarchis-Petmezas I998: 224).

Between the late $18^{\text {th }}$ century and the beginning of the $19^{\text {th }}$ demographic pressure, urbanization and commoditization influenced those communities belonging to the Aegean model of kinship and devolution while many parts of southern Greece reached a high level of demo-economic growth by the end of the $19^{\text {th }}$ century (Papataxiarchis-Petmezas I998: 232 and 238; Meraklis 2004: 58).

The different social and economic status of women transforms the symbolic value of spinning as well: it acquires an exchange or monetary value which functions as a factor of social inequality among the wealthier and the poorer women. The textile manufacture and industry, using mainly women, assigned to this activity a surplus value.

In the symbolic framework of the folktale, the status of the three spinning sisters alludes to these social inequalities. In this framework the inability to spin is transferred therefore from the daughters to the mother who, marked by the weakness of old age, is totally deprived of the characteristics of fertility and abundance. The fact that magic clothes and garments emerge from her bones is not attributed to an excess spinning ability but is now reframed by another belief system, that of the grateful dead, which is very common in Greek myth and folktale.

\section{Another spinning story: the legend of nifitsa}

Legends also deal with female antagonism to the accumulation of a dowry without which marriage is impossible: Politis in his Paradosis mentions three versions of an etiological legend told by many informants in southern Greece (Athens and the Peloponese) about the weasel (nifitsa in Greek, literally "little bride") (Politis I904: I83-I85; Abbott I9O3: IO8-I09). Other variants of the legend appear in other regions (see for example a variant from the village of Vourbiani, Epirus in Rembeli I953: I59-I60).

Nifitsa was once a bride but she was turned into an animal. She is jealous of all brides and destroys their dowries and clothing. To keep her happy, people put little spoons full of honey in the bedrooms (where dowries are usually stored). Nifitsa likes to spin, so they put a spindle full of cotton on the doorstep or the roof (Floudas I963, vol. 3: 62) for her to take instead of destroying their clothing.

A legend recently collected in the region of Arcadia, in the central Peloponnese sheds light on the reasons for Nifitsa's transformation into an animal, alluding again to female antagonism to spinning: a young girl was preparing her trousseau in preparation for marriage but her sister was married first and got all the dowry, 
leaving nothing for her. In other versions, the elder sister steals the trousseau and the heroine, out of grief, asks the Virgin Mary to transform her into a weasel so that she can search all the houses to find her belongings. So she turned bad and whenever she found some woolen clothes in a box she tore them all up, out of the hatred she had towards her sister who took her dowry. So the people in the village, especially marriageable young women, put a spindle with a little wool next to their clothes (or outside the hen-house) so that the nifitsa would spin thread to remake her dowry and not touch the clothes (or the hens). When a nifitsa sees a woman spinning she feels so happy that she dances around her. She also enjoys watching young girls spinning and weaving during the nichteria or washing their clothes in the rivers. Girls know that they should not laugh at her but praise her.

Southern Stachtopouta versions are therefore part of a larger folkloric cycle of narratives, customs and beliefs about spinning and the production of a dowry as a field of female antagonism. In the collective imagination, symbolic representations associated with spinning may reflect the changing social status of women in the family organization as it shifts from the extended family type to the nuclear domestic unit type. ${ }^{6}$ In this framework, the cannibalistic spinning bet could represent a symbolic extreme.

\section{The case of jokes and anecdotes about spinning}

Nevertheless, as part of a constant dialectical play, both female antagonism and women's solidarity is present in tales about spinning and dowry accumulation. This is evident from the numerous jokes, anecdotes, parodies or obscene stories told by women ridiculing social rules and conventions, and stereotyped gender roles. This was particularly important because the ideal model of a young girl or woman was one who spent a considerable time preparing her trousseau and this simply did not match reality. There are numerous anecdotes (for example, ATU I4O5 The Lazy Spinning Woman or the popular greek oikotypes 5I4C*, 902 *, " $\mathrm{I} 365$ ) about women who avoided spinning. Women are supposed to spin but as one of my informants mentioned in the mountainous village of Mellisourgoi (in the

\footnotetext{
6. The evolution from self-subsistence to commercial capitalism affected the pastoral societies of the Balkans as well. Using the example of the mountainous pastoral society of Metsovo in Epirus during the late Ottoman and post-Ottoman period, V. Rokou points out that, as social discrimination began to take shape, the pastoral group with the traditional family organization came to an end (Rokou 2007: I66-I68). As Gossiaux states, the participation of women in production was of crucial importance for the domestic organization in southslavic traditional society. As in every rural society based on self-subsistence, the domestic tasks in the household were already very heavy, but women had to work in the production as well. This wouldn't be possible, unless a very careful organization and distribution of the work inside the feminine collectivity was effectuated. Women constituted then a real entity, an autonomous sub-group inside the zadruga. Thus the snaha (the sisters-in-law of the zadruga), although individually subdued, they were, as a collectivity, the pedestal of the community. The autonomy of their organization was necessary for the function of the zadruga and was guaranteed by it. It is therefore not surprising that the zadruga started to disappear with the dislocation of the snaha. Testimonies make general allusions to the tensions and conflicts among women, in the last period of the extended south-slavic family. Every woman (more than every man) started to self-refer to her own conjugal universe and care for the future of her own children. The democracy of the brothers did not survive the division of the sisters-in-law (Gossiaux 1996: 200-20I).
} 
mountainous area of Tzoumerka, Central Greece), spinning was done by young girls in the sergiani (meaning outdoors, where there was also the opportunity to chat with other girls). Even the theme of the spinning contest has been parodied. A folktale from Thessaly describes a spinning contest among three sisters-in-law whose husbands are away at war: whoever drops the spindle first will be the one to sleep with their father in law. The two elder sisters-in-law willingly drop their spindle, and it is only the third one who keeps a firm hold of it, causing their envy.

\section{Conclusion}

Spinning therefore has a central place in the symbolic representation of a woman's status and social role in versions of Stachtopouta and Nifitsa. Nevertheless, the two distinct narrative traditions of the folktale as well as a number of intermediary versions reflect different levels of narrative appropriation of this theme. Northern Greek versions, which emerge from a well-established Balkan folkloric cycle, insert spinning in an old magico-ritualistic framework about birth, fertility and abundance. This magical framework of beliefs and practices seems to vanish from the oikotypical southern versions of the tale in which spinning acquires a rationalized economic value and reflects different ideas (which are even more discriminating towards women) about matrimonial practices and the accumulation of a dowry. Nevertheless, the magico-religious aspect is not absent from the southern versions, which reproduce an archaic cannibalistic motif connected with spinning. They also accentuate the role of women in the practice of funerary rites and the cult of the bones, becoming a source of abundance and wealth on the part of the mother as a figure of the grateful dead.

\section{References}

Аввотт, George Frederick (1903): Macedonian Folklore. Cambridge: Cambridge University Press.

AlEXAKIS, Eleftherios P. (I999-2003): "In Pursuit of Family Structures in Modern Greece: The Case of the Multi-nuclear Family". Annual of the Research Center For Hellenic Folklore no 29-30: 35-60.

ANGelopoulos, Anna (I989): "Fuseau de cendres". Cahiers de Littérature Orale no 25: 7I-95.

— (I99I): Paramythokores [Folktales' Heroines]. Athens: Hestia.

- (2013): Contes de la nuit grecque. Une anthologie commentée. Paris: Editions Corti.

BADA, Constantina (2002): "Drasis tis ylikis culturas kai mnimis: to kalamatiano metaxi apo tin pleura ton yphantrion". In M. Al. AlexiAdis (ed.): Thitia honorary volume to Profeesor M. G. Meraklis. Athens: University of Athens, p. 433-446.

Belmont, Nicole (20IO): Mythe, conte et enfance. Les écritures d'Orphée et de Cendrillon. Paris: L'Harmattan.

Ben-Amos, Dan (20II): Folktales of the Jews. Volume 3 Tales from Arab Lands. Philadelphia: the Jewish Publication Society. 
"Stachtopouta" and "Nifitsa": spinning tales in relation with feminine productivity ...

CAMPELL, John (1964): Honour, Family and Patronage: A Study of Institutions and Moral Values in a Greek Mountain Community. Oxford: Oxford University Press.

GossiauX, Jean-François (I996): "La snaha. Communauté familiale et statut de la femme chez les Slaves du sud”. Études Balkaniques no 3: I85-20I.

KATRINAKI, Emmanouela (2008): Le Cannibalisme dans le conte merveilleux grec. Questions d'interprétation et de typologie. Folklore Fellows' Communications 295. Helsinki: Suomalainen Tiedeakatemia.

Korre-Zografou, Katerina (2004-IO): Anthropoi kai paradosiaka epaggelmata sto Aigaio I - III. Athens: Foundation of the Hellenic World.

LAWSON, John Cuthbert (I9IO): Modern Greek folklore and ancient Greek religion: a study in survivals. Cambridge: Cambridge University Press.

LOUKATOS, Dimitris S. (I959): “To paramythi tis Staktoboutas stis xenes kai ellinikes parallages" [The folktale of Cinderella in foreign and Greek versions]. Parnassos no I: 46I-485.

MegAS, Georgios A. (I943-44): "Magikai kai deisidaimones synithiai pros apotropin epidimikon noson (tripoperasma, kainourgia fotia-diavolofotia, sidero" [Magic and superstitious habits for the prevention of epidemic diseases]. Epetiris tou Laographikou Arxeiou 5-6: 5-58.

MegAs, Georgios A. (I967): "Die Moiren als funktioneller faktor im Neugriechischen Märchen”. Laographia no 25: 316-332.

MegAs, Georgios A. et alii (2012): Catalogue of Greek Magic Folktales. Folklore Fellows' Communications 303. Helsinki: Suomalainen Tiedeakatemia.

MENCEJ, Mirjam (2OII): "Connecting threads". Folklore (Electronic Journal of Folklore) no 48: 66-69.

MeraKlis, M. G. (2004): Greek Folklore (in Greek). Athens: Odysseas Publications.

Papataxiarchis, Eythimios; Socrates D. Petmezas (I998): “The Devolution of Property and Kinship Practices in Late- and Post-Ottoman Ethnic Greek Societies. Some demo-economic factors of nineteenth and twentieth century transformations". Mélanges de l'Ecole française de Rome. Italie et Méditerranée no IIO/I: 2I7-24I.

Politis, N. G. (I904): Paradoseis [Legends]. Athens.

POLYMEROU-KAMILAKI, Aikaterini (20I3): “Otan svini i fotia...I diaxeirisi tis tefras" [When the fire goes out... The managing of the ashes]. In Maria Augouli; Eleni Romaiou-Karastamati and Giorgos SpeIs (eds.): I fotia pigi zois, dinamis kai katharmou [The fire, source of life, power and purification]. Athens: Melt: 3I-38.

ROKOU, Vasiliki (2007): Mountainous societies during the period of ottoman occupation in the Balkans: Pastoral Metsovo from the $I 7^{\text {th }}$ to the $2 O^{\text {th }}$ century (in Greek). Athens Erodios Publications.

Rooth, Anna Birgitta (I95I): The Cinderella Cycle. Lund: Gleerup.

SCHEID, John; Jesper Svenbro (2003): Le métier de Zeus: Mythe du tissage et du tissu dans le monde gréco-romain. Paris: Editions Errance.

Sergis, Manolis G. (2007): Rites of passage in Asia Minor Pontus (middle of Igth century - I922): Birth-Marriage-Death (in Greek). Athens: Herodotus. 
SICARD, Emile (I943): La zadruga sud-slave dans l'évolution du groupe domestique. Paris: Orphys.

Stoinnovich, Traian (I976): "The Balkan Domestic Family: Geography, Commerce, Demography". Revue des études sud-est européennes no I4/3: 465475 .

TING, Nai-tung (I974): The Cinderella Cycle in China and Indo-china. Folklore Fellows' Communications 213. Helsinki: Suomalainen Tiedeakatemia.

UTHER, Hans Jörg (2OII): The Types of International Folktales. A Classification and Bibliography. Part I-III. Folklore Fellows' Communications 284-286. Helsinki: Suomalainen Tiedeakatemia ( $I^{\text {st }}$ ed. 2004).

VAZ DA SilvA, Francisco (2000): "SymbolicThemes in the European Cinderella Cycle". Southern Folklore no 57/2: I59-I80.

- (2008): Archeology of Intangible Heritage. New York: Peter Lang.

- (20I4): "Why Cinderella's Mother Becomes a Cow". Marvels and Tales no 28/I: 25-37.

WeHSE, Rainer (I98I): “Cinderella (AaTh 5IOA)”. In Enzyklopädie des Märchens vol. 3: 39-57.

XANTHAKOU, Margarita (I995): Cendrillon et les soeurs cannibales. De la Staktobouta maniote (Grèce) à l'approche de l'anthropophagie intraparentale imaginaire. Paris: École des Hautes Études en Sciences Sociales.

ZiPES, Jack (I994): "Filer avec le destin. Rumpenstünzchen et le déclin de la productivité des femmes”. Europe no 787/788: IO6-II8.

\section{Sources}

\subsection{Unpublished sources}

Archive of the Greek Folklore Society: LF II65.

\subsection{Published sources}

Argenti Philip P.; H. J. Rose (I949): The Folklore of Chios (2 vols). Cambridge: University Press.

FloudAs, Nikolaos I. (I963): Vizikiotika. Vol. 3. Laographia [Folklore from Viziki]. Athens.

GEORGAMLIS, G. D. (2002): IStachtomaro kaialla paramythiatis Divris [Stacthomaro and other folktales from Divri]. Athens: Antiktipos.

HaHn, J. G. von (1864): Griechische und Albanesische Märchen. Leipzig.

IOANNOU, George (I975): Paramythia tou laou mas [Folktales of our people]. Athens: Hermes.

KASsis, Kyriakos D. (2007): Maniatika Paramythia [Folktales from Mani]. Athens.

Kougeas Socratis B. (2009): Out' ego imoun ekei...out ki eseis na to pistepsete. Paramythia kai tragoudia apo ti Monemvasia, ti Milo, tin Androusa. Syllogi Kosta Gounari (I906-I909) [Neither I was there... neither you to believe it. Folktales 
"Stachtopouta" and "Nifitsa": spinning tales in relation with feminine productivity ... and songs from Monemvasia, Milo, Androusa. Collected by Kostas Gounaris (I906-I909)].

LOUKATOS, D. I. (I977): “Kefalliniakes parallages tou paramythiou tis Stachtopoutas" [Versions of Cinderella from Kefallonia]. Kefalliniaka Chronika no 2: 266-289.

PAPADOPOUlos, Dimitrios (I937): “I Sachtaritsa". Pontiaka Phylla no I5: I57-I60.

PAPANIKOLAOU, Photis (I999): Laographika Voiou [Folklore of Voion]. Kozani: Insitutou Vivliou kai Anagnosis.

PAPAZISI-PAPATHEOdorou, Zoi (I996): Paramythia ton Vlachon. 96 paramythia periochis Trikalon Thessalias [Folktales from the Vlachs. 96 folktales from the region of Trikala, Thessaly]. Athens: Gutenberg.

PARCHARIDIS, I. (I885): "I Sachtaritsa". Astir tou Pontou no I4: 2I3-2I7.

Pousios, Th. (I884): "Syllogi lejeon, paramythion, asmaton ktl. toy en Zagorio tis Hpirou ellhnikoy laou" [Collection of words, folktales, songs etc. from the Greek people of Zagori, Epirus]. Journal of the Hellenic Philological Society of Constantinople no I4 (I879-80): 205-277.

Rembeli, Char. (I953): Konitsiotika [Folklore from Konitsa]. Athens: Epirotiki Etaireia Athinon.

RIGAS, Georgios A. (I962): Skiathou laikos politismos [Folklore of Skiathos]. Vol. 2. Thessaloniki: Etaireia Makedonikon Spoudon.

SAKellariou, Athanasios A. (I89I): Ta Kypriaka (vol. 2). Athens: P.D. Sakellariou.

Theochari, Maria (I994): Paramythia kai Paramythades. Syllogi mathiton Gymnasioy Doriou Messinias [Folktales and Storytellers. Collection by pupils of Dorion Highschool in Messinia]. Athens: Zita.

Venetoulias, Giorgis (2OOI). Paramythia tis Kythnou [Folktales from Kythnos]. Kythnos: Municipality of Kythnos.

Virvillis, Zisimos (I996): Ta Paramythia tis Patmou [Folktales from Patmos]. Athens.

ZOGRAFAKIS, Ioannou N. (I886): To paramythi tis Stachtopoutas ejetazomenon ypo istorikin epojin [The folktale of Cinderella studied from a historical perspective]. Herakleion: Ch. P. Lydakis.

ZuCCARINI (I832): "Märchen und Kinderspiele in Griechenland”. Das Ausland no 58: 230. 